\title{
The Works of Ibn Wāḍị̣ al-Ya'qūbì (Volume 1)
}

\author{
Matthew S. Gordon, Chase F. Robinson, \\ Everett K. Rowson, and Michael Fishbein, eds. \\ Boston: Brill, 2017. 260 pages.
}

Following the monumental translation project of al-Ṭabarìs History (40 vols., Albany: SUNY Press), completed in 2007, the editors of this three-volume work have supervised the translation of the writings of another important early historian: Ibn Wādih al-Ya'qūbī (d. shortly after 295/908). It contains fully annotated translations of al-Ya'qūbī's History (Tärīkh), his Geography (Kitāb al-buldān), his short political essay The Book of the Adaption of Men to Their Time and Their Dominant Characteristics in Every Age (Mushākalat al-nās li-zamānihim wa-mā yaghlibu 'alayhim fì kull 'așr) and a few fragmentary texts found in other pre-modern Arabic works. The first volume (the subject of this review) contains The Adaption of Men, The Geography, and the fragmentary texts, while the latter two volumes contain The History divided into two parts. Because of their early date and richness of information on a wide range of historical subjects, al-Ya'qūbī’s works are important sources to consider for anyone interested in early Islamic history and the historical tradition that developed in the first centuries AH. That 
was also, as stated in the introduction, the main reason for this translation project that took over two decades to complete.

In the first introductory chapter (1:1-8), Matthew S. Gordon makes clear that the translation project sought to address two main groups of readers: (1) "scholars in related fields who, in most cases, are unable to read al-Ya'qūbì in the original Arabic" and (2) "students of early Near Eastern and Islamic history" (1:2). These are important clarifications and answers to the question that might otherwise arise: What is the use of translating these rather specialized Arabic texts into English? One answer is, as Gordon points out, that they are useful to scholars in related fields. In the case of al-Ya'qūbì, considering his broad interests as a historian and geographer, the translation of his works will be particularly useful for historians of Late Antiquity from outside the field of Arabic and Islamic studies. Another answer would be, as also pointed out, that they are useful for undergraduate and graduate students of Islamic history, as well as teachers and course organizers, who usually have to rely on texts in translation. A third answer that is not explored in the introduction-except perhaps alluded to in the reference to the translation of al-Tabarīs History as an "invaluable resource for scholars and students alike" (1:2) - is that critical and fully-annotated translations of classical works may function as "commentaries" on the original Arabic texts and can thus be useful to scholars who are capable of reading the original texts. This is, for example, how the translation of alTabarîs History has often been used; scholars may (or rather should) read the text in the original Arabic, but for clarifications of difficult passages, meanings of certain words in context or questions how to translate terms or passages, they may consult the critical and annotated translations. Gordon's introduction briefly introduces al-Ya'qūbī and his three surviving works, noting their general content, some of their characteristics and, especially in relation to The History, al-Ya'qūbỉs Shì'i views and his "Shi'ite reading of Islamic history" (1:5). The introduction is useful in what it contains, but would have benefitted from a more thorough discussion of how al-Ya ${ }^{c} q u \overline{b i}$ worked as a historian and geographer-including subjects such as his intellectual context, audience, sources, methods of compilation, and historical views. Instead, it is simply noted that some of these topics "deserve further investigation" (1:6).

The second introductory chapter contains a "biographical sketch" of al-Ya'qūbì by Sean Anthony and Matthew S. Gordon (1:9-22). Despite the scarcity of biographical information ("there is little that can be known for certain about al-Ya' qūbī and his life," 1:10), Anthony and Gordon provide a 
useful summary of what we can know about him, based on a few accounts of other historians who cite his works and what might be inferred from his own writings: his hardline Shīism, the works he compiled, the approximate date of his death (shortly after 295/908), his many travels, some of the places in which he lived from al-Fustāt to Ișfahān, his links to certain dynasties (Ṭāhirids in Iran and Ṭūlūnids in Egypt), his involvement in the bureaucratic circles of the 'Abbāsid era and his particular attachment to, and historical interest in, the 'Abbāsid dynasty. Either here or in the first introductory chapter, however, a lot more could be said about al-Ya' qūbì as a historian and a geographer; after all, what we really know about him and have access to is the results of his historical and geographical writings: The History and The Geography.

The third and final introductory chapter, by Everett K. Rowson, outlines the manuscripts, printed editions and translations of al-Ya'qūbỉs three works (1:23-27). Rowson notes "that three of al-Ya'qübï's works have been preserved, although not in optimal form, and that they have received considerable scholarly attention" (23). Most of the discussion pertains to The History. He points out that there are two more or less identical surviving manuscripts of The History, one of which is based on the other. The standard and "only respectable" Arabic edition of the text (ed. M. Th. Houtsma, 2 vols., Leiden: Brill, 1883) is based on the later of the two manuscripts, while the translators in this project have prioritized the earlier one as the "only independent source for text readings" and mainly used the later copy (including Houtsma's published edition) for interpretations of words and phrases that are hard to read. This raises the question if it would not have been a good idea to provide a critical edition of the Arabic text before a translation (of the manuscript text) into English; after all, a new critical and accessible edition of the original Arabic text is needed in the field. However, it is possible that such a project of re-editing al-Ya qūbīs History is already underway, which would make this question unnecessary.

The first of the three volumes contains the translation of The Adaption of Men (31-60, trans. Michael Fishbein), The Geography (64-199, trans. Elton Daniel and Paul M. Cobb), and some fragmentary texts (203-34, trans. Cobb, Gordon and Fishbein). The first is a short political essay comprised of chronologically arranged anecdotes about the caliphs-beginning with Abū Bakr (r. 11-13/632-4) and ending with al-Mu'tadid (r. 27989/892-902) - and examples of how the people of their times, according to al-Ya ${ }^{c} q u \bar{b} \bar{i}$, tended to follow them in their conduct and tastes. Fishbein's translation is clear and the annotation is very informative, essentially func- 
tioning as a useful commentary with information about mentioned individuals, places, and events as well as clarifications of terms and difficult passages. It is interesting to note that al-Ya 'quibīs image of the first three caliphs is surprisingly positive for a "hardline" Shīi ì historian-Abū Bakr, for example, is described as "the most abstemious of men, the most humble and sparing in his clothing" and 'Umar, among other things, as "strict in matters relating to God" (31-33) — which might illustrate the difficulty of categorizing al-Ya ${ }^{c} q u \bar{b} i_{s}$ Shicism.

The second translated text is The Geography, which, as Gordon notes, is a book of "administrative geography" that al-Ya quibī seems to have compiled in order to "provide his fellow regional functionaries with the kind of information required to carry out their administrative duties" (6). It contains descriptions of the major towns and cities in the Muslim world of al-Ya'qūbī's time and information about practical matters such as distances, agriculture, crafts, products, successions of governors, and the religious and ethnic composition of the local populations. The translation is clear and very readable, despite the sometimes difficult terminology and numerous place names, and the annotation is extensive and useful. Altogether, this translation of al-Ya'qübì's works is a very welcomed addition to the field of early Islamic history and historiography, comparable in this respect to the translation of al-Tabarîs History, which has proven its importance for both students and scholars. Similar to that project, the translations of alYa 'qübỉs writings are carried out by twelve specialists in the field, which is evident from the translated texts as well as the accompanying annotations and the concise but useful introductory material. One does, however, hope that the translations will be complemented by new critical editions of the Arabic texts, at least in the case of The History, and new detailed historiographical studies on al-Ya ${ }^{c}$ qūbì as a historian and as a geographer.

Tobias Andersson

Faculty Member

Department of Theology

Uppsala University 